\title{
THE FIFTH SYMPOSIUM ON APPLIED MATHEMATICS
}

The Fifth Symposium on Applied Mathematics of the American Mathematical Society was held at the Carnegie Institute of Technology, Pittsburgh, Pennsylvania, on Monday and Tuesday, June 16-17, 1952. The subject of the Symposium was Wave motion and vibration theory. Attendance at each of the sessions was approximately 100. The following 119 persons, including 64 members of the Society, attended.

L. R. Alldredge, Julius Ashkin, S. B. Batdorf, E. G. Begle, R. A. Berg, Walker Bleakney, J. L. Bogdanoff, J. I. Bohnert, G. F. Carrier, Subrahmanyan Chandrasekhar, C. C. Chang, Abraham Charnes, Peter Chiarulli, Norman Davids, C. R. DePrima, F. C. DeSua, G. P. Dinneen, R. C. DiPrima, W. S. Dorn, R. J. Duffin, Nat Edmonson, J. J. Eisenhuth, T. A. Elkins, Sabri Ergün, R. L. Evans, J. B. Fanucci, H. E. Fettis, E. T. Frankel, J. B. Freier, Bernard Friedman, P. R. Garabedian, A. Garren, Edward Gerjuoy, R. D. Glanz, H. J. Greenberg, Mayo Greenberg, P. N. Gustafson, George Habetler, G. H. Handelman, H. W. Handsfield, Duncan Harkin, C. D. Harris, A. E. Heins, G. S. Heller, R. G. Helsel, D. S. Hoffman, J. P. Hoyt, W. S. Jardetzky, Fritz John, W. P. Jones, Edna Keitzer, T. B. Khammash, Martin Krakowski, J. M. Lande, E. H. Lee, Solomon Lefschetz, G. F. Leger, C. E. Lemke, Martin Lessen, Harold Levine, H. G. Lew, J. A. Lewis, C. C. Lin, B. W. McCormick, N. W. McLachlan, S. S. McNeary, Wilhelm Magnus, L. E. Malvern, M. H. Martin, R. C. Meacham, C. T. Molloy, E. W. Montroll, T. W. Moore, G. W. Morgan, David Moskovitz, C. E. Mullan, D. J. Newman, Simon Ostrach, N. A. Patton, W. H. Pell, R. C. Prim, Eric Reissner, L. P. Rosenberry, E. A. Saibel, S. A. Schelkunoff, M. E. Scherberg, Albert Schild, Morris Schulkin, R. J. Seeger, Hyman Serbin, D. H. Shaffer, R. Skinner, M. F. Smith, Marvin Stern, Eli Sternberg, Andrew Sterrett, J. J. Stoker, T. T. Tanimoto, Olga Taussky, J. S. Taylor, M. O. Taylor, T. Theodorsen, W. B. Thompson, John Todd, L. R. Turner, H. C. Volkin, E. G. Volterra, J. C. Warner, W. H. Warner, B. R. Weber, Herschel Weil, E. B. Weinberger, Alexander Weinstein, H. J. Weiss, Paul Weiss, Bernard Weitzer, E. A. Whitman, W. R. K. Wu, Arthur Zeichner.

Dormitories, lounges, and dining facilities were made available to those attending the Symposium by the host institution. On Monday afternoon, Symposium members were guests of the Department of Mathematics at a tea, held in the Exhibition Room of the Fine Arts Building, and on Monday evening at a social gathering, held in the Faculty Club.

Dr. J. C. Warner, President of the Carnegie Institute of Technology, extended greetings from the Institute to Symposium members at the first session on Monday morning.

The program of the Symposium consisted of 15 invited addresses. The papers were presented in the following order (in those cases where two authors are named, the paper was presented by the firstnamed author). 
1. C. C. Lin: Hydrodynamic stability.

2. Subrahmanyan Chandrasekhar: The stability of fluid motion in the presence of the magnetic field.

3. P. R. Garabedian: On free surface flows.

4. G. F. Carrier and W. H. Munk: On the diffusion of tides into permeable rock.

5. J. J. Stoker: Water waves.

6. Walker Bleakney: Review of significant observations on the Mach reflection of shock waves.

7. N. W. McLachlan: On the solution of non-linear differential equation to hydraulics.

8. E. W. Montroll and Mayo Greenberg: Scattering of plane waves by a soft obstacle.

9. Harold Levine: Variational methods in boundary value problems.

10. Wilhelm Magnus: Infinite matrices associated with a diffraction problem.

11. A. E. Heins and H. Feshbach: On the coupling of two half planes.

12. E. H. Lee: Wave propagation in helical compression springs.

13. Alexander Weinstein and J. B. Diaz: On the wave equation and the equation of Euler-Poisson.

14. Solomon Lefschetz: On the Lienard equation.

15. R. J. Duffin and Albert Schild: On some vibration problems.

The presiding officers at the sessions were, respectively, Professor Peter Chiarulli, Dr. T. Theodorsen, Dr. S. A. Schelkunoff, and Professor E. A. Saibel.

At the beginning of the last session, a resolution of thanks to the Carnegie Institute of Technology, the Department of Mathematics, and the Committee on Arrangements was adopted unanimously.

The papers presented at the Symposium will be published as Volume V of the Proceedings of the Symposia in Applied Mathematics by the McGraw-Hill Book Company.

A. E. Heins,

Chairman of the Committee

on Arrangements
E. G. BEGLE, Secretary of the Society 